\title{
Insulin Resistance in Pregnancy Is Correlated with Decreased Insulin Receptor Gene Expression in Omental Adipose: Insulin Sensitivity and Adipose Tissue Gene Expression in Normal Pregnancy
}

\author{
Arnold M. Mahesan1*, Dotun Ogunyemi², Eric Kim³ ${ }^{3}$ Anthea B. M. Paul2, Y.-D. Ida Chen ${ }^{3}$ \\ ${ }^{1}$ Jones Institute for Reproductive Medicine, Eastern Virginia Medical School, Norfolk, VA, USA \\ ${ }^{2}$ Department of Obstetrics and Gynecology, Oakland University William Beaumont School of Medicine; Royal \\ Oak, MI, USA \\ ${ }^{3}$ LA Biomedical Research Center, Harbor-UCLA Medical Center, Torrance, CA, USA \\ Email: *am.mahesan@gmail.com
}

Received 4 August 2015; accepted 25 February 2016; published 29 February 2016

Copyright (C) 2016 by authors and Scientific Research Publishing Inc.

This work is licensed under the Creative Commons Attribution International License (CC BY). http://creativecommons.org/licenses/by/4.0/

(c) (7) Open Access

\section{Abstract}

Aims: To determine correlations of insulin sensitivity to gene expression in omental and subcutaneous adipose tissue of non-obese, non-diabetic pregnant women. Methods: Microarray gene profiling was performed on subcutaneous and omental adipose tissue from 14 patients and obtained while fasting during non-laboring Cesarean section, using Illumina HumanHT-12 V4 Expression BeadChips. Findings were validated by real-time PCR. Matusda-Insulin sensitivity index (IS) and homeostasis model assessment of insulin resistance (HOMA-IR) were calculated from glucose and insulin levels obtained from a frequently sampled oral glucose tolerance test, and correlated with gene expression. Results: Of genes differentially expressed in omental vs. subcutaneous adipose, in omentum 12 genes were expressed toward insulin resistance, whereas only 5 genes were expressed toward insulin sensitivity. In particular, expression of the insulin receptor gene (INSR), which initiates the insulin signaling cascade, is strongly positively correlated with IS and negatively with HOMA-IR in omental tissue $(r=0.84)$. Conclusion: Differential gene expression in omentum relative to subcutaneous adipose showed a pro-insulin resistance profile in omentum. A clinical importance of omental adipose is observed here, as downregulation of insulin receptor in omentum is correlated with increased systemic insulin resistance.

\footnotetext{
"Corresponding author.
}

How to cite this paper: Mahesan, A.M., et al. (2016) Insulin Resistance in Pregnancy Is Correlated with Decreased Insulin Receptor Gene Expression in Omental Adipose: Insulin Sensitivity and Adipose Tissue Gene Expression in Normal Pregnancy. Journal of Diabetes Mellitus, 6, 100-111. http://dx.doi.org/10.4236/jdm.2016.61011 


\section{Keywords}

\section{DEG, Insulin Resistance, Insulin Sensitivity, Insulin Signaling Pathway, Adipose Tissue in Pregnancy, Carbohydrate Metabolism, Diabetic Pathways}

\section{Introduction}

Various metabolic pathways are involved in glucose homeostasis and in the development of insulin resistance. The insulin signaling pathway is initiated when insulin binds to its receptor resulting in the tyrosine phosphorylation of insulin receptor substrates (IRS) by the insulin receptor tyrosine kinase (INSR). Tyrosine phosphorylated IRS in turn activates phosphoinositide 3-kinase (PI3K), which further activates Akt. Activated Akt induces glycogen synthesis by inhibiting glycogen synthase kinase 3 (GSK-3), and facilitates mTOR-mediated activation of protein synthesis and cell survival. The PI3k/Akt pathway further stimulates the translocation of GLUT4 vesicles to the plasma membrane and allows the uptake of glucose into muscle and adipose cells [1]-[3].

The role of adipose tissue in the pathophysiology of insulin resistance is well recognized [1] [4]. Pregnancy is associated with insulin resistance and increases risks of gestational diabetes mellitus (GDM) and type II diabetes mellitus (T2DM) [5] [6]. In pregnancy, the cellular mechanisms for decreased insulin sensitivity are multifactorial, involving both skeletal muscle and adipose tissue and remain to be completely elucidated [1] [4]. Human pregnancy is characterized by adipose tissue accretion in early gestation, followed by insulin resistance and facilitated lipolysis in late pregnancy [7]-[9]. Additionally, the adipose tissue transcriptome demonstrates the recruitment of metabolic and immune molecular networks by 8 - 12 weeks of gestation, preceding any pregnancyrelated physiological changes associated with insulin resistance [9].

Studies investigating insulin-signaling intermediates have demonstrated reduced IRS-1 protein levels, reduced GLUT4 translocation and subsequent glucose uptake in adipose tissue of obese women with GDM, and T2DM in comparison to controls [10]-[14].

These previous reports studied obese women and those with GDM or T2DM, analyzing mainly subcutaneous adipose tissue. There is data demonstrating that visceral adipose tissue accumulation increases the risk for developing obesity-related diseases such as T2DM, and cardiovascular diseases [15] [16]. Consequently, our study focused on the comparative roles of visceral versus subcutaneous adipose tissue. Furthermore, by choosing to include healthy, non-diabetic, non-obese pregnant women in the current analysis, we are able to examine the function of visceral and subcutaneous adipose tissue in pregnancy without confounding factors that may be associated with disease states.

The objectives of our study were two-fold. The first was to characterize in healthy, non-obese pregnant women differentially expressed genes in visceral and subcutaneous adipose tissue with a focus on insulin signaling, carbohydrate metabolism, and diabetic pathways [17]. The second was to determine associations between systemic insulin sensitivity and gene expression in visceral and subcutaneous adipose tissue.

\section{Materials and Methods}

\subsection{Adipose Tissue Collection}

Non-obese healthy pregnant women between the ages of 18 to 45 years old were recruited during prenatal care. Women who were scheduled for an elective cesarean delivery and had a normal glucose challenge test were included. After obtaining informed consent and routine prenatal care, during the cesarean delivery, maternal blood, cord blood, subcutaneous adipose tissue samples (from the abdominal wall at the edge of the surgical incision), and omental adipose tissue samples were all obtained. The adipose tissues were flash frozen in liquid nitrogen and stored in a $-80^{\circ} \mathrm{C}$ freezer. The Cedars-Sinai Medical Center Institutional Review Board approved the study.

\subsection{RNA Extraction and Labeling}

Total RNA was extracted from adipose tissues using RNeasy Lipid Tissue kit from Qiagen following the manufacturer's instructions. Biotin-labeled cRNA synthesis and amplification was performed using Illumina Total Prep RNA Amplification kit (Ambion) following manufacturers protocol. 


\subsection{Microarray Hybridization, Staining and Scanning}

Biotin labeled cRNA (750 ng) was loaded on to Illumina HumanHT-12 V4.0 Expression BeadChip in hybridization buffer with hybridization controls and incubated for 16 hours at $58^{\circ} \mathrm{C}$. After hybridization, BeadChips were washed, blocked with blocking buffer, and stained with streptavidin-Cy3 (Amersham Biosciences). Images of stained BeadChips were captured by Illumina BeadArray Reader.

\subsection{Microarray Image Processing and Data Analysis}

BeadChip images were loaded into Illumina GenomeStudio for quality determination by evaluation of the present call percentages, signal intensities of hybridization control, biotin controls, and negative controls, with quantile normalization. Signal intensities of each gene/probe were exported into Partek Genomic Suite 6.5 and ANOVA model was used to evaluate the impacts of various variables in the study such as different adipose tissues, patient ethnicity, patient-to-patient variability, etc., on the expression data set. Differentially expressed genes of subcutaneous versus omental adipose tissue were defined as a 1.5-fold difference in either direction plus pair-wise $t$-test. Benjamini \& Hochberg procedure was applied with a false discovery rate (FDR) threshold of $\mathrm{p}<0.05$ to adjust for multiple testing. DAVID Bioinformatics Resources 6.7 was used to conduct functional classification and pathway analysis (National Institute of Allergy and Infectious Diseases, NIAID, NIH) [18][20].

\subsection{Real-Time PCR Validation of Microarray Results}

Quantitative RT-PCR was used to verify the differential expression level of several genes. A ratio greater than 1 reflected a greater level of transcript expression within the omental adipose group compared with the subcutaneous adipose group. We selected the genes that had the highest fold change in the analysis (CLDN1, CFB) as well as six genes (IL-6, IL-1B, SLC2A1, HSD11B1, ADIPOQ, IRS1, PLA2G2A) that had well recognized insulin signaling, inflammatory and metabolic function.

RNA was first reverse-transcribed to cDNA using iScript Reverse Transcription Supermix for RT-qPCR (Bio-rad). About $10 \mathrm{ng}$ cDNA were mixed with gene specific primers and Platinum Sybr Green qPCR SuperMix-UDG (Invitrogen). Real-time PCR was carried out in ABI 7000 Sequence Detector (AppliedBiosystems) for 40 cycles. The expression level of human GAPDH gene was used as an internal control, and fold changes of omental adipose group versus subcutaneous group were calculated using $\Delta \mathrm{CT}$ method.

\subsection{Matusda-Insulin Sensitivity Calculation}

On 11 subjects, a frequently Sampled Oral Glucose Tolerance Test (FSOGTT) was performed. Patients had to be on a 300 grams carbohydrate per day diet. After obtaining a fasting blood sample, a 75 gram glucose solution was ingested orally. Blood samples were obtained every 15 minutes for 3 hours. Glucose and insulin levels were determined and recorded. Insulin sensitivity was calculated using Matsuda index. Matusda et al. developed an index of whole-body insulin sensitivity using 10,000/(square root of fasting glucose $\times$ fasting insulin $\times$ mean glucose $\times$ mean insulin during OGTT), which is highly correlated with the rate of whole-body glucose disposal during the euglycemic insulin clamp [21]. The homeostasis model assessment of insulin resistance (HOMA-IR) index, the product of basal glucose and insulin levels divided by 22.5 [22], is regarded as a simple, reliable measure of insulin resistance. HOMA-IR was calculating according to the following formula: fasting insulin $(\mu \mathrm{IU} / \mathrm{ml}) \times$ fasting glucose $(\mathrm{mmol} / \mathrm{ml}) / 22.5[23]$.

\subsection{Gene Mapping}

DEGs were mapped to the Kyoto Encyclopedia of Genes and Genomes (KEGG) pathways; a collection of pathway maps representing current knowledge on molecular interaction and reaction networks classified as Global, Metabolism, Genetic Information Processing, Environmental Information Processing, Cellular Processes, Organismal Systems, Human Diseases and Drug Development with each molecular interaction and reaction network including multiple pathways [17]. Utilizing NIH David [19], Gene Card [24], KEGG pathway database [17], and PubMed [25], extensive review was done of known functions of DEGs in regards to gene tendency towards insulin resistance (IR) or insulin sensitivity (IS). In this review, DEGs whose cellular function would 
cause decreased plasma glucose level or facilitate insulin action were classified as insulin sensitive and genes whose functions would cause increased plasma glucose levels or block insulin action were classified as insulin resistant.

Pearson's correlation test was applied for transcript expression levels and insulin sensitivity scores. Separate analyses were performed for subcutaneous and visceral adipose tissues. Gene transcripts determined to be significantly correlated with both HOMA-IR score and Matsuda index were selected for pathway analysis. A cutoff p-value of $<0.01$ was used to determine significance.

\section{Results}

\subsection{Demographic and Categorical Factors}

The study is based on 14 patients who had an elective Cesarean section performed between 2008 and 2010. Patients were screened for any pre-existing diabetic condition; oral glucose tolerance test results were normal and excluded gestational diabetes. The mean age was 32.1 years $(\mathrm{SD}=6.21)$, the mean $\mathrm{BMI}$ was $23.3(\mathrm{SD}=2.88)$, the mean gestational age at delivery was $39+0 / 7$ weeks ( $\mathrm{SD}=4.37$ days), and the mean birth weight was 3240 grams (SD = 384.7 grams) (Table 1 ).

Categorical factors including fat, BMI, and race were analyzed using ANOVA to gauge each factor's contribution and for allowing the identification of significant sources of variation. Factors having a ratio greater than 1 were considered significant and not attributable to error. Adipose tissue had almost a five-fold effect with an $\mathrm{F}$ ratio of 4.77. BMI had a ratio of 2.02, highlighting the impact of BMI. Anticipating this factor, the study was planned to minimize the effect of obesity by excluding from the study any women with a BMI of 30 (classified as obese). Race had a ratio of 1.8. Although the race factor is higher than can be attributed to error, comparing the interaction of race with adipose tissue on differential gene expression using a mixed model ANOVA showed an effect of only 1.25, suggesting minimal impact of race on the differential gene expression of adipose tissue (Figure 1).

Table 1. Demographic data of the study population.

\begin{tabular}{|c|c|c|c|c|c|c|}
\hline & Race & Age & Gestational AGE & Birth weight & Weight at Delivery & $\mathrm{BMI}^{*}$ \\
\hline Patient 1 & Afr Am & 33 & $40+0$ & 3213 & 75.8 & 22.2 \\
\hline Patient 2 & Afr Am & 28 & $39+0$ & 3950 & 77.1 & 25.5 \\
\hline Patient 3 & Afr Am & 41 & $39+1$ & 3210 & 88.9 & 26.3 \\
\hline Patient 4 & Asian & 30 & $39+5$ & 2760 & 59.0 & 20.7 \\
\hline Patient 5 & Asian & 31 & $38+2$ & 3230 & 78.9 & 23.0 \\
\hline Patient 6 & Caucasian & 20 & $39+0$ & 3400 & 75.4 & 20.8 \\
\hline Patient 7 & Caucasian & 38 & $39+0$ & 3493 & 89.0 & 22.3 \\
\hline Patient 8 & Caucasian & 36 & $37+2$ & 2850 & 78.4 & 24.9 \\
\hline Patient 9 & Hispanic & 37 & $39+0$ & 2769 & 56.7 & 18.7 \\
\hline Patient 10 & Hispanic & 37 & $39+0$ & 3420 & 58.0 & 21.0 \\
\hline Patient 11 & Hispanic & 26 & $39+1$ & 3460 & 82.6 & 21.7 \\
\hline Patient 12 & Hispanic & 38 & $38+5$ & 2630 & 77.1 & 23.0 \\
\hline Patient 13 & Hispanic & 32 & $39+0$ & 3760 & 84.8 & 25.8 \\
\hline Patient 14 & Hispanic & 23 & $38+5$ & 3210 & 95.3 & 29.7 \\
\hline Mean & & 32.1 & $39+0$ & 3240 & 77.0 & 23.3 \\
\hline SD & & 6.21 & 4.37 days & 384.7 & 12.3 & 2.88 \\
\hline
\end{tabular}

Gestational Age given in number of weeks + days/7. Birth weight in grams. Age in years. BMI = Pre-pregnancy body mass index; Afr Am = African American. 


\subsection{Upregulated and Downregulated Genes in KEGG Pathways}

In the comparison of omental versus subcutaneous adipose tissue, 920 genes showed significant relative fold change of expression level, of which 332 genes showed decreased expression levels and 588 genes showed increased expression levels.

We focused our analysis on the 17 differentially expressed genes in the insulin signaling (Figure 2), diabetic (Figure 3) and carbohydrate metabolism KEGG pathways that were associated in the literature with insulin sensitivity or resistance.

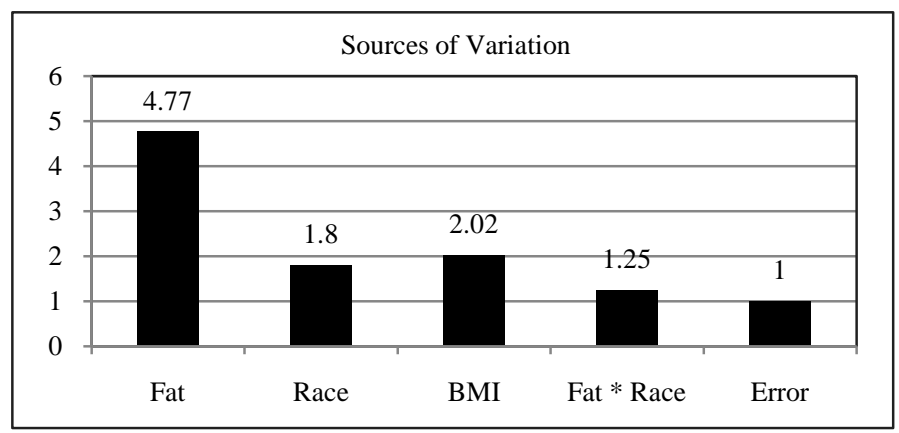

Figure 1. ANOVA model used to evaluate the impacts of the potential confounding variables: fat, race, BMI, fat and race in the differentially expressed genes in the study population. The horizontal column indicates the Mean $\mathrm{F}$ Ratio while the various factors analyzed in the multi factor ANOVA are listed horizontally along the xaxis. Any factor that has a Mean F Ratio more than error (1) is considered "significant".

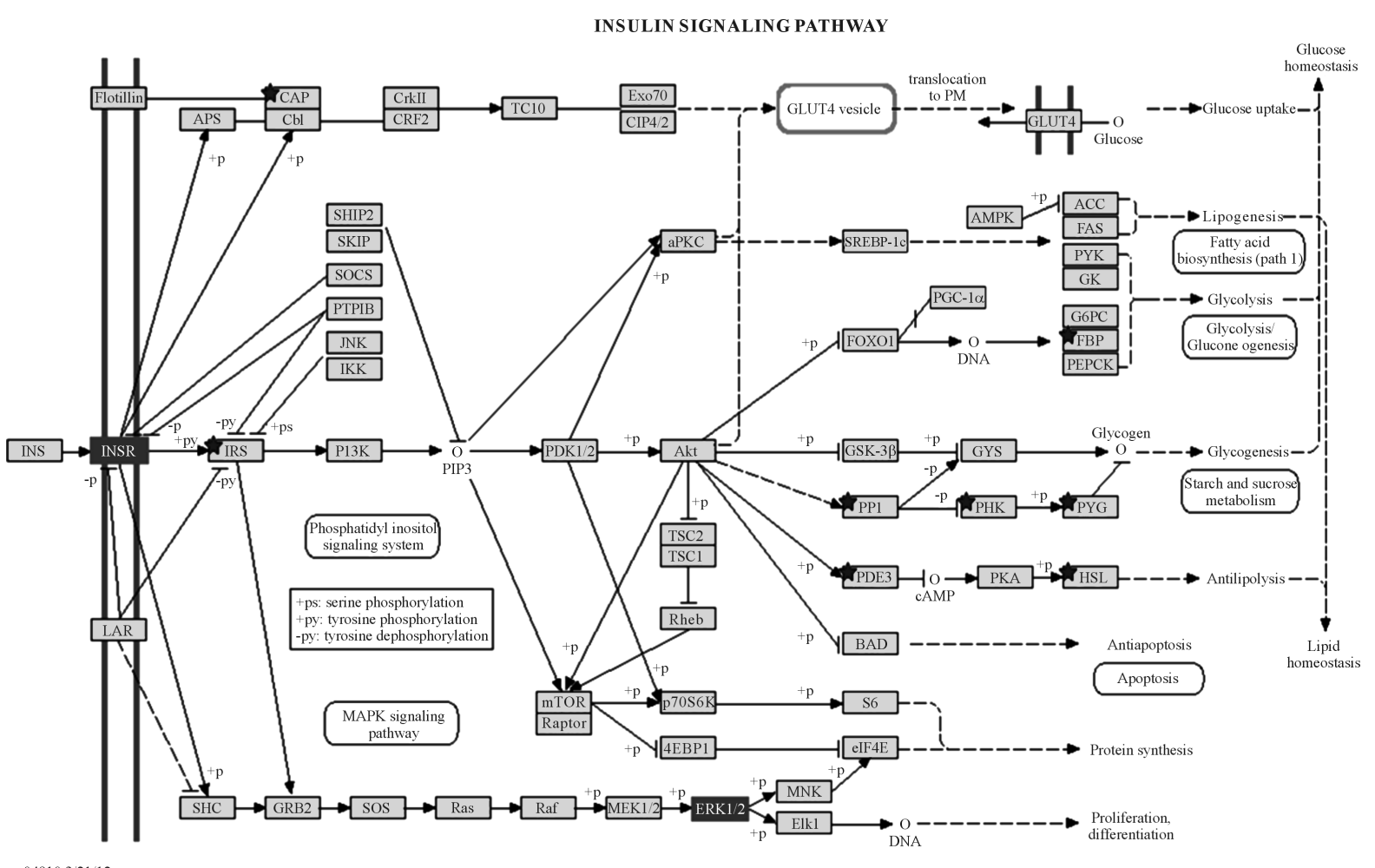

$049103 / 21 / 12$

Figure 2. Graphic representation of KEGG insulin signaling pathway. Genes marked with stars are significantly differentially expressed in omental versus subcutaneous adipose tissue. 


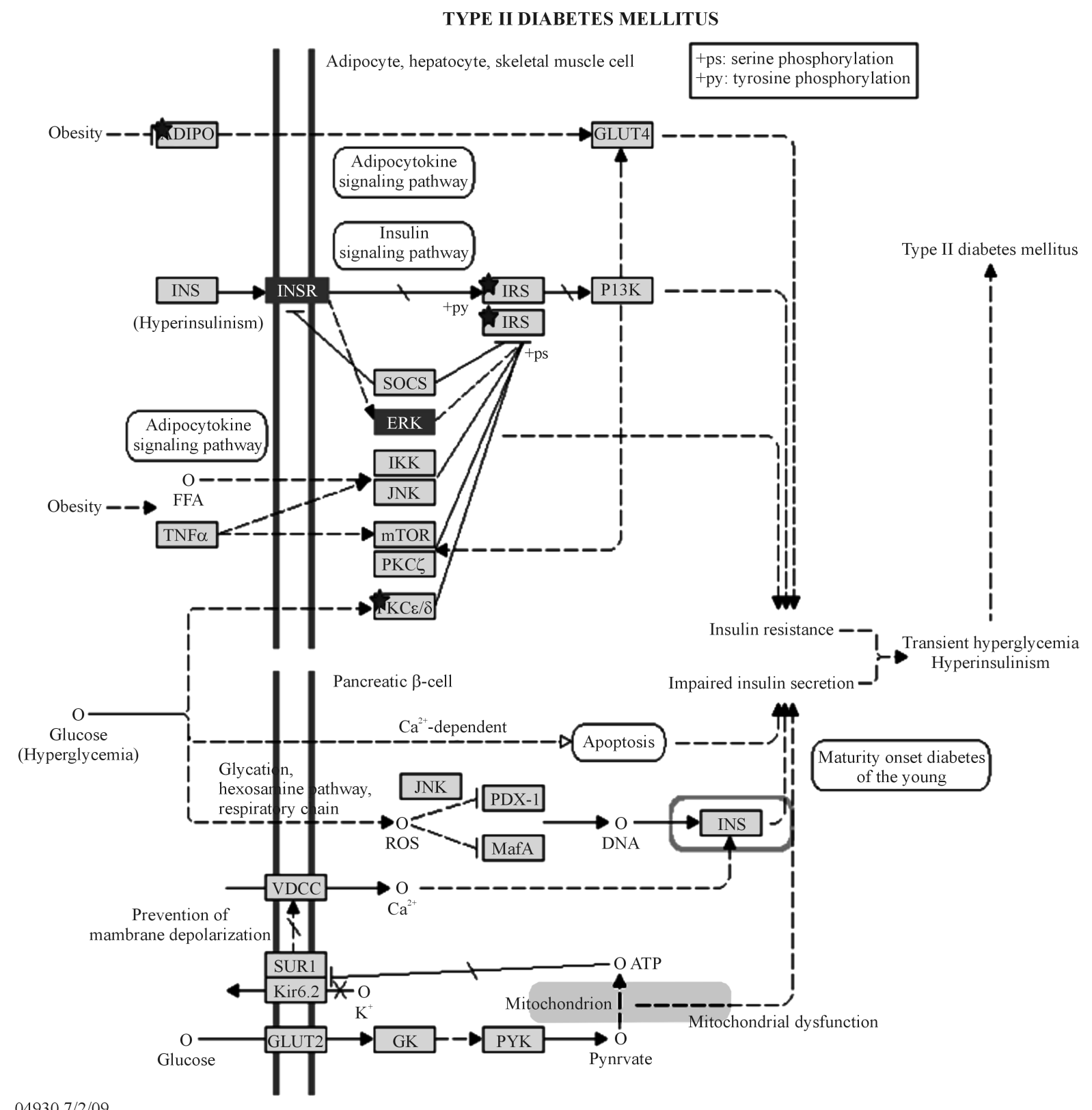

$049307 / 2 / 09$

(c) Kanehisa Laboratories

Figure 3. Graphic representation of KEGG Type II diabetes mellitus pathway. Genes marked with stars are significantly differentially expressed in omental versus subcutaneous adipose tissue.

\subsection{Genes Differentially Expressed Towards Increased Insulin Sensitivity}

2 upregulated genes in omental adipose were associated with increased insulin sensitivity: Protein phosphatase 1, regulatory (inhibitor) subunit 3C (PPP1R3C), and Phosphofructokinase, muscle (PFKM).

3 downregulated genes were associated with increased insulin resistance: Phosphorylase kinase, delta (PHK), Protein kinase C delta (PRKCD), Phosphorylase, glycogen, liver (PYGL) (Table 2).

\subsection{Genes Differentially Expressed toward Increased Insulin Sensitivity}

2 upregulated genes in omental adipose were associated in the literature with increased insulin resistance: FBP1 and GFPT2. 
Table 2. Genes differentially expressed towards insulin sensitivity in omental vs. subcutaneous adipose.

\begin{tabular}{|c|c|c|c|c|}
\hline Symbol & Gene Name & Gene Function & $\begin{array}{l}\text { Microarray } \\
\text { Fold Change }\end{array}$ & p-Value \\
\hline PHK & Phosphorylasekinase, delta & $\begin{array}{l}\text { Catalyzes phosphorylation of serine in substrates. } \\
\text { Increases glycogenolysis. }\end{array}$ & -1.743 & $6.50 \mathrm{E}-06$ \\
\hline PRKCD & Protein kinase $\mathrm{C}$ delta & $\begin{array}{l}\text { Functioning as a pro-apoptotic protein during DNA } \\
\text { damage-induced apoptosis, may impair insulin } \\
\text { secretion due to apoptosis. }\end{array}$ & -1.63 & $6.28 \mathrm{E}-05$ \\
\hline PYGL & $\begin{array}{l}\text { Phosphorylase, } \\
\text { glycogen, liver }\end{array}$ & $\begin{array}{l}\text { Rate-determining enzyme catalyzing } \\
\text { glycogen degradation. }\end{array}$ & -1.50 & $1.66 \mathrm{E}-03$ \\
\hline PPP1R3C & $\begin{array}{l}\text { Protein phosphatase 1, } \\
\text { regulatory (inhibitor) } \\
\text { subunit 3C }\end{array}$ & $\begin{array}{c}\text { Activates glycogen synthase, reduces glycogen } \\
\text { phosphorylase activity and limits glycogen breakdown. } \\
\text { Dramatically increases basal and insulin-stimulated } \\
\text { glycogen synthesis. }\end{array}$ & +1.69 & $1.37 \mathrm{E}-03$ \\
\hline PFKM & $\begin{array}{l}\text { Phosphofructokinase, } \\
\text { muscle }\end{array}$ & $\begin{array}{l}\text { Catalyzes the phosphorylation of fructose-6-phosphate to } \\
\text { fructose-1,6-bisphosphate, prior to its cleavage into } \\
\text { glyceraldehyde-3-phosphate which enters the } \\
\text { energy generation phase of glycolysis. }\end{array}$ & +2.27 & $1.47 \mathrm{E}-07$ \\
\hline
\end{tabular}

10 downregulated DEG associated with increased insulin sensitivity were identified: GBE1, LIPE, SORBS1, IRS1, ADIPOQ, PFKFB3, ME1, IDH1, ACSS2, PFKFB1 (Table 3).

\subsection{Correlation of Insulin Sensitivity and HOMA-IR with Differentially Expressed Genes}

In the second stage of our study, we evaluated the correlation between insulin sensitivity (IS), HOMA-IR, with gene expression in omental and subcutaneous tissue.

In subcutaneous tissue, expression of 22 genes correlated significantly with IS. Of these, 15 had a negative correlation with IS and 7 had a positive correlation with IS. Only 5 genes matched to known genes in NIH David database with none mapping to the insulin signaling, diabetic, or carbohydrate metabolism pathways.

In omental adipose, 509 genes significantly correlated with IS. Of these, 325 matched to known genes in NIH David database. Of these, 2 genes were in the insulin signaling or type 2 diabetic KEGG pathways.

Two genes, insulin receptor (INSR) and mitogen-activated protein kinase 3 (MAPK1), strongly positively correlated with IS (Table 4).

\subsection{Real-Time PCR Validation of Microarray Results}

Table 5 shows the quantitative RT-PCR results for the nine positional candidate genes and confirms the differential expression of all upregulated genes and downregulated genes with the microarray analysis. For example, for the CFB gene the microarray fold change was 10.62 and the RT-PCR fold change was 11.6.

\section{Discussion}

Pregnancy is associated with a decrease in insulin sensitivity of $50 \%-60 \%$ by the latter half of pregnancy with a $200 \%-250 \%$ increase in insulin secretion to maintain euglycemia [26]. Adipose tissue plays a central role in the development of insulin resistance because it is insulin responsive and contributes directly, although quantitatively less than skeletal muscle, to the whole-body glucose disposal [1] [4] [8] [27] [28]. Our results suggest that omental tissue in comparison to subcutaneous adipose tissue may have more metabolic pathways alterations that affect carbohydrate metabolism and insulin function, which may contribute to the decreased insulin sensitivity in pregnancy.

In the insulin-signaling pathway, 4 genes were differentially expressed towards decreased insulin sensitivity in omental vs. subcutaneous adipose. IRS1 is downregulated, and it is a crucial gene in insulin sensitivity because it mediates the various cellular processes of insulin [11] [17] [29] [30]. Also downregulated are sorbin and SH3 domain containing 1 (SORBS1), required for insulin-stimulated glucose transport [31], and Lipase, hormone-sensitive (LIPE), shown to have decreased activity in insulin resistant and obese states [32] [33]. Fructose-1,6- 
Table 3. Genes differentially expressed towards insulin resistance in omental vs. subcutaneous adipose.

\begin{tabular}{|c|c|c|c|c|}
\hline Symbol & Gene Name & Gene Function & $\begin{array}{l}\text { Microarray } \\
\text { Fold Change }\end{array}$ & p-Value \\
\hline FBP1 & fructose-1,6-bisphosphatase 1 & $\begin{array}{l}\text { Gluconeogenesis regulatory enzyme, catalyzes the hydrolysis } \\
\text { of fructose 1,6-bisphosphate to fructose 6-phosphate and } \\
\text { inorganic phosphate. upregulation of FBPase in pancreatic } \\
\text { islet beta-cells, as occurs in states of lipid oversupply and } \\
\text { type } 2 \text { diabetes, contributes to insulin secretory dysfunction. }\end{array}$ & +1.72 & $2.32 \mathrm{E}-03$ \\
\hline GFPT2 & $\begin{array}{c}\text { glutamine-fructose-6-phosphate } \\
\text { transaminase } 2\end{array}$ & $\begin{array}{l}\text { Controls the flux of glucose into the hexosamine pathway. } \\
\text { Regulates availability of precursors for glycosylation of } \\
\text { proteins. Increased GFAT activity appears to be associated } \\
\text { with insulin resistance, postprandial hyperglycaemia and } \\
\text { oxidative stress in T2DM. }\end{array}$ & +3.47 & $1.68 \mathrm{E}-05$ \\
\hline GBE1 & $\begin{array}{l}\text { glucan (1,4-alpha-), } \\
\text { branching enzyme } 1\end{array}$ & $\begin{array}{l}\text { Required for sufficient glycogen accumulation. The alpha } \\
1 \text { - } 6 \text { branches of glycogen play an important role in } \\
\text { increasing the solubility of the molecule and, consequently, } \\
\text { in reducing the osmotic pressure within cells. }\end{array}$ & -4.27 & 0.000493696 \\
\hline LIPE & Lipase, hormone-sensitive & $\begin{array}{l}\text { In adipose tissue, it hydrolyzes stored triglycerides to free } \\
\text { fatty acids. Rate-limiting enzyme responsible for triglyceride } \\
\text { breakdown. Decreased in IR and obese states }\end{array}$ & -2.36 & $7.33 \mathrm{E}-04$ \\
\hline SORBS1 & $\begin{array}{l}\text { sorbin and SH3 domain } \\
\text { containing } 1\end{array}$ & Required for insulin-stimulated glucose transport. & -2.20 & $2.34 \mathrm{E}-04$ \\
\hline IRS1 & Insulin receptor substrate 1 & $\begin{array}{l}\text { Mediates cellular processes of insulin. Mutations } \\
\text { associated with type II diabetes and insulin resistance. }\end{array}$ & -1.78 & $1.46 \mathrm{E}-05$ \\
\hline ADIPOQ & Adiponectin & $\begin{array}{l}\text { Important adipokine involved in the control of fat } \\
\text { metabolism and insulin sensitivity, with direct anti-diabetic, } \\
\text { anti-atherogenic and anti-inflammatory activities. Stimulates } \\
\text { AMPK phosphorylation and activation in the liver and the } \\
\text { skeletal muscle, enhancing glucose utilization and fatty-acid } \\
\text { combustion. Antagonizes TNF-alpha. Inhibits endothelial } \\
\text { NF-kappa-B signaling through a cAMP-dependent pathway. }\end{array}$ & -1.67 & $3.98 \mathrm{E}-02$ \\
\hline PFKFB3 & $\begin{array}{l}\text { 6-phosphofructo-2-kinase/ } \\
\text { fructose-2,6-biphosphatase } 3\end{array}$ & $\begin{array}{l}\text { Catalyzes the synthesis and degradation of fructose } \\
\text { 2,6-bisphosphate (F2,6BP), which is a powerful activator } \\
\text { of 6-phosphofructo-1-kinase, the rate-limiting enzyme of } \\
\text { glycolysis. Induced by insulin in adipose tissue. }\end{array}$ & -1.67 & 0.0053397 \\
\hline ME1 & $\begin{array}{l}\text { Malic enzyme 1, } \\
\text { NADP(+)-dependent, cytosolic }\end{array}$ & $\begin{array}{l}\text { Reversible oxidative decarboxylation of malate, } \\
\text { links the glycolytic and citric acid cycle. }\end{array}$ & -1.64 & 0.00107314 \\
\hline IDH1 & $\begin{array}{l}\text { Isocitratedehydrogenase } 1 \\
(\mathrm{NADP}+) \text {, soluble }\end{array}$ & $\begin{array}{l}\text { Catalyze the oxidative decarboxylation of isocitrate } \\
\text { to 2-oxoglutarate. Significant role in cytoplasmic } \\
\text { NADPH production. }\end{array}$ & -1.63 & 0.000787487 \\
\hline ACSS2 & $\begin{array}{l}\text { acyl-CoAsynthetase short-chain } \\
\text { family member } 2\end{array}$ & $\begin{array}{l}\text { Catalyzes the activation of acetate for use in lipid } \\
\text { synthesis and energy generation }\end{array}$ & -1.60 & 0.000415893 \\
\hline PFKFB1 & $\begin{array}{l}\text { 6-phosphofructo-2-kinase/ } \\
\text { fructose-2,6-biphosphatase } 1\end{array}$ & $\begin{array}{c}\text { Activates glycolysis \& inhibits gluconeogenesis. } \\
\text { Regulate glucose homeostasis. }\end{array}$ & -1.51 & 0.0133634 \\
\hline
\end{tabular}

Table 4. Correlations between insulin sensitivity, HOMA-R and microarray differential gene expression mapping to KEGG insulin signaling, type 2 diabetes mellitus and carbohydrate metabolism pathways in omental tissue of healthy non-obese pregnant women.

\begin{tabular}{ccccc}
\hline Gene Name & Gene Symbol & $\begin{array}{c}\text { Rho } \\
\text { (ISI Matsuda Index) }\end{array}$ & $\begin{array}{c}\text { p-Value } \\
\text { (ISI Matsuda Index) }\end{array}$ & HOMA IR, Rho \\
\hline Mitogen-activated protein kinase 3 & MAPK1 (ERK) & 0.78 & 0.004 & -0.52 \\
Insulin receptor & INSR & 0.84 & 0.001 & -0.64 \\
\hline
\end{tabular}

Legend: ISI matsuda: Matusda-Insulin sensitivity index; HOMA IR: homeostasis model assessment of insulin resistance; Rho: correlation coefficient. 
Table 5. Real-time PCR validation of microarray results.

\begin{tabular}{|c|c|c|c|c|}
\hline \multirow{2}{*}{ Gene } & \multirow{2}{*}{ Gene Name } & \multirow{2}{*}{ Ref_seq } & \multicolumn{2}{|c|}{ Fold Change } \\
\hline & & & Microarray & RT-PCR \\
\hline IL-6 & & NM_000600 & 2.19 & 1.23 \\
\hline IL-1B & & NM_000576 & 2.00 & 1.31 \\
\hline CLDN1 & & NM_021101 & 18.61 & 13.89 \\
\hline SLC2A1 & & NM_006516 & 1.59 & 1.93 \\
\hline HSD11B1 & & NM_181755 & 2.60 & 1.95 \\
\hline ADIPOQ & & NM_004797 & -1.67 & -1.58 \\
\hline CFB & & NM_001710 & 10.62 & 11.60 \\
\hline IRS1 & & NM_005544 & -1.77 & -1.48 \\
\hline PLA2G2A & & NM_000300 & 4.48 & 3.50 \\
\hline
\end{tabular}

Ref_Seq = reference sequence.

bisphosphatase 1 (FBP1) is upregulated, and it is associated with decreased insulin sensitivity because it regulates gluconeogenesis and has been shown to contribute to insulin secretory dysfunction [34].

In the insulin signaling pathway, 3 genes were differentially expressed towards increased insulin sensitivity in omental vs. subcutaneous adipose. Two genes are downregulated: phosphorylase, glycogen, liver (PYGL) which is involved in glycogen degradation [35], and calmodulin 1, phosphorylase kinase, delta (PHK), which increases glycogenolysis [36]. One gene is upregulated: protein phosphatase 1, regulatory (inhibitor) subunit 3C (PPP1R3C), which is associated with insulin sensitivity because it activates glycogen synthase, reduces glycogen phosphorylase activity and limits glycogen breakdown [37].

In the Type-2 diabetic pathway, Adiponectin was downregulated in omental adipose compared with subcutaneous adipose. Adiponectin is an endogenous insulin-sensitizing hormone, which has anti-diabetic, anti-atherogenic and anti-inflammatory roles [30]. Decreased serum levels of adiponectin in early pregnancy have been shown to predict increased risks of GDM [4] [8].

Several genes of carbohydrate metabolism were differentially expressed in omental versus subcutaneous adipose towards insulin resistance. 6-phosphofructo-2-kinase/fructose-2,6-biphosphatase 3 (PFKFB3) [38] [39] was downregulated in omental versus subcutaneous adipose. PFKFB3 is associated with increased insulin sensitivity because it is the rate-limiting enzyme in glycolysis. Glycolysis involves the anerobic breakdown of glucose to two pyruvates. Pyruvate is converted to acetyl CoA, which enters the TCA cycle. The TCA cycle is used aerobically to generate energy through the oxidization of acetate, derived from carbohydrates, fats and proteins, to carbon dioxide [17] [40]. Other downregulated genes associated with increased insulin sensitivity include other TCA and glycolytic pathway genes (Table 1), 1,4-alpha-glucan-branching enzyme 1 (GBE1) which is required for glycogen accumulation [41] [42], and inositol 1,3,4-triphosphate 5/6 kinase (ITPK1) which inhibits TNF alpha induced cell death [43]. Glutamine-fructose-6-phosphate transaminase (GFPT2), associated with insulin resistance and oxidative stress, was upregulated [44]. Further, phosphofructokinase muscle (PFKM), a major insulin glycolytic gene [45] [46], was downregulated, while aldehyde dehydrogenase 3 family, member B1 (ALDH3B1), which converted acetaldehyde to acetate for glycolysis [47] [48], was upregulated in omental vs. subcutaneous adipose.

We identified 5 genes involved in the insulin signaling, diabetic and carbohydrate metabolism pathways in omental adipose that showed significant correlations with IS and HOMA-IR but none in subcutaneous adipose. Insulin sensitivity was strongly positively correlated with insulin receptor (INSR) [49] [50] gene expression in omental adipose $(\mathrm{r}=0.84)$. Insulin receptor binds insulin and is thus a key mediator of the metabolic effects of insulin. MAPK1 [51] [52], which regulates protein synthesis in response to insulin and is associated with cell survival, is also strongly positively correlated $(r=0.78)$ with insulin sensitivity.

Our findings support and add to previously published studies on adipose tissue. We show a decrease in expression of IRS-1 in omental adipose as compared with subcutaneous adipose, which has been observed in pre- 
vious studies [10]-[12] [14] [53]. However, we did not find a difference in GLUT4 [13] [14] or in GS activity and GSK-3 expression as in other studies [14] [30]. Notably, previous reports studied diseased states (obesity, GDM and T2DM), and since we investigated only normal non-obese individuals, we would expect the cellular defects to be milder. We further found decreased expressions of adiponectin, glycolysis and TCA genes in omental adipose.

Furthermore, we showed a strong positive correlation between insulin receptor gene expression in omental adipose and systemic insulin sensitivity, with no correlation seen in subcutaneous tissue. This finding suggests the clinical significance of omental adipose of systemic insulin resistance in our study, and calls for further elucidation of the potential role of omental adipose in the pathophysiology of insulin resistance in pregnancy.

\section{Disclosure}

None of the authors have a conflict of interest

\section{References}

[1] Catalano, P.M. (2010) Obesity, Insulin Resistance, and Pregnancy Outcome. Reproduction, 140, 365-371. http://dx.doi.org/10.1530/REP-10-0088

[2] Ding, A. Insulin Receptor Signaling Pathway. http://www.cellsignal.com/reference/pathway/Insulin_Receptor.html

[3] Kanehisa Laboratories. Insulin Signaling Pathway, KEGG Database. http://www.genome.jp/kegg/pathway/hsa/hsa04910.html

[4] Barbour, L.A., McCurdy, C.E., Hernandez, T.L., Kirwan, J.P., Catalano, P.M. and Friedman, J.E. (2007) Cellular Mechanisms for Insulin Resistance in Normal Pregnancy and Gestational Diabetes. Diabetes Care, 30, S112-S119. http://dx.doi.org/10.2337/dc07-s202

[5] Centers for Disease Control and Prevention (2008) National Diabetes Fact Sheet: General Information and National Estimates on Diabetes in the United States, 2007. U.S. Department of Health and Human Services, Centers for Disease Control and Prevention, Atlanta.

[6] American College of Obstetricians and Gynecologists (2001) Gestational Diabetes. ACOG Practice Bulletin No. 30. Obstetrics \& Gynecology, 98, 525-538.

[7] Bergman, R.N., Kim, S.P., Catalano, K.J., et al. (2006) Why Visceral Fat Is Bad: Mechanisms of the Metabolic Syndrome. Obesity, 14, 16S-19S. http://dx.doi.org/10.1038/oby.2006.277

[8] Valsamakis, G., Kumar, S., Creatsas, G. and Mastorakos, G. (2010) The Effects of Adipose Tissue and Adipocytokines in Human Pregnancy. Annals of the New York Academy of Sciences, 1205, 76-81. http://dx.doi.org/10.1111/j.1749-6632.2010.05667.x

[9] Resi, V., Basu, S., Haghiac, M., et al. (2012) Molecular inflammation and adipose tissue matrix remodeling precede physiological adaptations to pregnancy. American Journal of Physiology-Endocrinology and Metabolism, 303, E832E840. http://dx.doi.org/10.1152/ajpendo.00002.2012

[10] Friedman, J.E., Ishizuka, T., Shao, J., Huston, L., Highman, T. and Catalano, P. (1999) Impaired Glucose Transport and Insulin Receptor Tyrosine Phosphorylation in Skeletal Muscle from Obese Women with Gestational Diabetes. Diabetes, 48, 1807-1814. http://dx.doi.org/10.2337/diabetes.48.9.1807

[11] Catalano, P.M., Nizielski, S.E., Shao, J., Preston, L., Qiao, L. and Friedman, J.E. (2002) Downregulated IRS-1 and PPAR Gamma in Obese Women with Gestational Diabetes: Relationship to FFA during Pregnancy. American Journal of Physiology: Endocrinology and Metabolism, 282, E522-E533. http://dx.doi.org/10.1152/ajpendo.00124.2001

[12] Tomazic, M., Janez, A., Sketelj, A., Kocijancic, A., Eckel, J. and Sharma, P.M. (2002) Comparison of Alterations in Insulin Signaling Pathway in Adipocytes from Type II Diabetic Pregnant Women with Gestational Diabetes Mellitus. Diabetologia, 45, 502-508. http://dx.doi.org/10.1007/s00125-002-0791-Z

[13] Garvey, W.T., Maianu, L., Zhu, J.H., Hancock, J.A. and Golichowski, A.M. (1993) Multiple Defects in the Adipocyte Glucose Transport System Cause Cellular Insulin Resistance in Gestational Diabetes. Heterogeneity in the Number and a Novel Abnormality in Subcellular Localization of GLUT4 Glucose Transporters. Diabetes, 42, 1773-1785. http://dx.doi.org/10.2337/diab.42.12.1773

[14] Colomiere, M., Permezel, M. and Lappas, M. (2010) Diabetes and Obesity during Pregnancy Alter Insulin Signalling and Glucose Transporter Expression in Maternal Skeletal Muscle and Subcutaneous Adipose Tissue. Journal of Molecular Endocrinology, 44, 213-223. http://dx.doi.org/10.1677/JME-09-0091

[15] Linder, K., Arner, P., Flores-Morales, A., Tollet-Egnell, P. and Norstedt, G. (2004) Differentially Expressed Genes in Visceral or Subcutaneous Adipose Tissue of Obese Men and Women. The Journal of Lipid Research, 45, 148-154. 
http://dx.doi.org/10.1194/jlr.M300256-JLR200

[16] Lee, Y.H., Nair, S., Rousseau, E., Allison, D.B., Page, G.P., Tataranni, P.A., Bogardus, C. and Permana, P.A. (2005) Microarray Profiling of Isolated Abdominal Subcutaneous Adipocytes from Obese vs Non-Obese Pima Indians: Increased Expression of Inflammation-Related Genes. Diabetologia, 48, 1776-1783.

http://dx.doi.org/10.1007/s00125-005-1867-3

[17] Kanehisa Laboratories. KEGG Pathway Database. Accessed 10 December 2013. http://www.genome.jp/kegg/pathway.html

[18] Huang, D.W., Sherman, B.T. and Lempicki, R.A. (2009) Systematic and Integrative Analysis of Large Gene Lists Using DAVID Bioinformatics Resources. Nature Protocols, 4, 44-57. http://dx.doi.org/10.1038/nprot.2008.211

[19] Huang, D.W., Sherman, B.T. and Lempicki, R.A. (2009) Bioinformatics Enrichment Tools: Paths toward the Comprehensive Functional Analysis of Large Gene Lists. Nucleic Acids Research, 37, 1-13. http://dx.doi.org/10.1093/nar/gkn923

[20] National Institute of Allergy and Infectious Diseases (NIAID), NIH. DAVID Bioinformatics Resources 6.7. http://david.abcc.ncifcrf.gov

[21] Matsuda, M. and DeFronzo, R.A. (1999) Insulin Sensitivity Indices Obtained from Oral Glucose Tolerance Testing: Comparison with the Euglycemic Insulin Clamp. Diabetes Care, 22, 1462-1470. http://dx.doi.org/10.2337/diacare.22.9.1462

[22] Matthews, D.R., Hosker, J.P., Rudenski, A.S., Naylor, B.A., Treacher, D.F. and Turner, R.C. (1985) Homeostasis Model Assessment: Insulin Resistance and Beta-Cell Function from Fasting Plasma Glucose and Insulin Concentrations in Man. Diabetologia, 28, 412-419. http://dx.doi.org/10.1007/BF00280883

[23] Song, Y., Manson, J.E., Tinker, L., Howard, B.V., Kuller, L.H., Nathan, L., et al. (2007) Insulin Sensitivity and Insulin Secretion Determined by Homeostasis Model Assessment (HOMA) and Risk of Diabetes in a Multiethnic Cohort of Women: The Women's Health Initiative Observational Study. Diabetes Care, 30, 1747-1752. http://dx.doi.org/10.2337/dc07-0358

[24] Crown Human Genome Center, Weizmann Institute of Science. GeneCards. Accessed 5 March 2013. http://www.genecards.org

[25] National Institutes of Health. PubMed. Accessed 5 March 2013. http://www.ncbi.nlm.nih.gov/pubmed

[26] Catalano, P.M., Huston, L., Amini, S.B. and Kalhan, S.C. (1999) Longitudinal Changes in Glucose Metabolism during Pregnancy in Obese Women with Normal Glucose Tolerance and Gestational Diabetes Mellitus. American Journal of Obstetrics \& Gynecology, 180, 903-916. http://dx.doi.org/10.1016/S0002-9378(99)70662-9

[27] Hajer, G.R., van Haeften, T.W. and Visseren, F.L.J. (2008) Adipose Tissue Dysfunction in Obesity, Diabetes, and Vascular Diseases. European Heart Journal, 29, 2959-2971. http://dx.doi.org/10.1093/eurheartj/ehn387

[28] Stump, C.S., Henriksen, E.J., Wei, Y. and Sowers, J.R. (2006) The Metabolic Syndrome: Role of Skeletal Muscle Metabolism. Annals of Medicine, 38, 389-402. http://dx.doi.org/10.1080/07853890600888413

[29] Draznin, B. (2006) Molecular Mechanisms of Insulin Resistance: Serine Phosphorylation of Insulin Receptor Substrate-1 and Increased Expression of p85alpha: The Two Sides of a Coin. Diabetes, 55, 2392-2397.

[30] Patel, S., Doble, B.W., MacAulay, K., Sinclair, E.M., Drucker, D.J. and Woodgett, J.R. (2008) Tissue-Specific Role of Glycogen Synthase Kinase 3 Beta in Glucose Homeostasis and Insulin Action. Molecular and Cellular Biology, 28, 6314-6328. http://dx.doi.org/10.1128/MCB.00763-08

[31] Crown Human Genome Center, Weizmann Institute of Science. Sorbin and SH3 Domain Containing 1 . Accessed 5 March 2013. http://www.genecards.org/cgi-bin/carddisp.pl?gene=SORBS1

[32] Jocken, J.W., Langin, D., Smit, E., Saris, W.H., Valle, C., Hul, G.B., Holm, C., Arner, P. and Blaak, E.E. (2007) Adipose Triglyceride Lipase and Hormone-Sensitive Lipase Protein Expression Is Decreased in the Obese Insulin-Resistant State. The Journal of Clinical Endocrinology \& Metabolism, 92, 2292-2299. http://dx.doi.org/10.1210/jc.2006-1318

[33] Jocken, J.W., Roepstorff, C., Goossens, G.H., van der Baan, P., van Baak, M., Saris, W.H.M., Kiens, B. and Blaak, E.E. (2008) Hormone-Sensitive Lipase Serine Phosphorylation and Glycerol Exchange across Skeletal Muscle in Lean and Obese Subjects: Effect of Beta-Adrenergic Stimulation. Diabetes, 57, 1834-1841. http://dx.doi.org/10.2337/db07-0857

[34] Kebede, M., Favaloro, J., Gunton, J.E., Laybutt, D.R., Shaw, M., Wong, N., Fam, B.C., Aston-Mourney, K., Rantzau, C., Zulli, A., Proietto, J. and Andrikopoulos, S. (2008) Fructose-1,6-bisphosphatase Overexpression in Pancreatic Beta-Cells Results in Reduced Insulin Secretion: A New Mechanism for Fat-Induced Impairment of Beta-Cell Function. Diabetes, 57, 1887-1895. http://dx.doi.org/10.2337/db07-1326

[35] Burwinkel, B., Bakker, H.D., Herschkovitz, E., Moses, S.W., Shin, Y.S. and Kilimann, M.W. (1998) Mutations in the Liver Glycogen Phosphorylase Gene (PYGL) Underlying Glycogenosis Type VI. The American Journal of Human 
Genetics, 62, 785-791. http://dx.doi.org/10.1086/301790

[36] Maichele, A.J., Burwinkel, B., Maire, I., Søvik, O. and Kilimann, M.W. (1996) Mutations in the Testis/Liver Isoform of the Phosphorylase Kinase Gamma Subunit (PHKG2) Cause Autosomal Liver Glycogenosis in the Gsd Rat and in Humans. Nature Genetics, 14, 337-340. http://dx.doi.org/10.1038/ng1196-337

[37] Crown Human Genome Center, Weizmann Institute of Science. Protein Phosphatase 1, Regulatory Subunit 3C. http://www.genecards.org/cgi-bin/carddisp.pl?gene=PPP1R3C\&search=PPP1R3C

[38] Atsumi, T., Nishio, T., Niwa, H., Takeuchi, J., Bando, H., Shimizu, C., Yoshioka, N., Bucala, R. and Koike, T. (2005) Expression of Inducible 6-phosphofructo-2-kinase/fructose-2,6-bisphosphatase/PFKFB3 Isoforms in Adipocytes and Their Potential Role in Glycolytic Regulation. Diabetes, 54, 3349-3357. http://dx.doi.org/10.2337/diabetes.54.12.3349

[39] Huo, Y., Guo, X., Li, H., Xu, H., Halim, V., Zhang, W., et al. (2012) Targeted Overexpression of Inducible 6-phosphofructo-2-kinase in Adipose Tissue Increases Fat Deposition but Protects against Diet-Induced Insulin Resistance and Inflammatory Responses. The Journal of Biological Chemistry, 287, 21492-21500. http://dx.doi.org/10.1074/jbc.M112.370379

[40] Kanehisa Laboratories. Type I Diabetes Mellitus-Homo Sapiens, KEGG Database. http://www.genome.jp/kegg/pathway/hsa/hsa04940.html

[41] Kanehisa Laboratories. Citrate Cycle (TCA Cycle). http://www.genome.jp/kegg/pathway/map/map00020.html

[42] Crown Human Genome Center, Weizmann Institute of Science. Glucan (1,4-Alpha-), Branching Enzyme 1. http://www.genecards.org/cgi-bin/carddisp.pl?gene=GBE1\&search=GBE1

[43] Sun, Y., Mochizuki, Y. and Majerus, P.W. (2003) Inositol 1,3,4-trisphosphate 5/6-kinase Inhibits Tumor Necrosis Factor-Induced Apoptosis. The Journal of Biological Chemistry, 278, 43645-43653. http://dx.doi.org/10.1074/jbc.M300674200

[44] Srinivasan, V., Sandhya, N., Sampathkumar, R., Farooq, S., Mohan, V. and Balasubramanyam, M. (2007) Glutamine Fructose-6-phosphate Amidotransferase (GFAT) Gene Expression and Activity in Patients with Type 2 Diabetes: Inter-Relationships with Hyperglycaemia and Oxidative Stress. Clinical Biochemistry, 40, 952-957. http://dx.doi.org/10.1016/j.clinbiochem.2007.05.002

[45] Ristow, M., Vorgerd, M., Möhlig, M., Schatz, H. and Pfeiffer, A. (1999) Insulin Resistance and Impaired Insulin Secretion Due to Phosphofructo-1-kinase-deficiency in Humans. Journal of Molecular Medicine, 77, 96-103. http://dx.doi.org/10.1007/s001090050311

[46] García, M., Pujol, A., Ruzo, A., Riu, E., Ruberte, J., Arbós, A., Serafín, A., Albella, B., Felíu, J.E. and Bosch, F. (2009) Phosphofructo-1-kinase Deficiency Leads to a Severe Cardiac and Hematological Disorder in Addition to Skeletal Muscle Glycogenosis. PLoS Genetics, 5, e1000615. http://dx.doi.org/10.1371/journal.pgen.1000615

[47] Wang, Y., Ng, M.C., Lee, S.C., So, W.-Y., Tong, P.C.Y., Cockram, C.S., Critchley, J.A.J.H. and Chan, J.C.N. (2003) Phenotypic Heterogeneity and Associations of Two Aldose Reductase Gene Polymorphisms with Nephropathy and Retinopathy in Type 2 Diabetes. Diabetes Care, 26, 2410-2415. http://dx.doi.org/10.2337/diacare.26.8.2410

[48] Neamat-Allah, M., Feeney, S.A., Savage, D.A., Maxwell, A.P., Hanson, R.L., Knowler, W.C., El Nahas, A.M., Plater, M.E., Shaw, J., Boulton, A.J.M., Duff, G.W. and Cox, A. (2001) Analysis of the Association between Diabetic Nephropathy and Polymorphisms in the Aldose Reductase Gene in Type 1 and Type 2 Diabetes Mellitus. Diabetic Medicine, 18, 906-914. http://dx.doi.org/10.1046/j.0742-3071.2001.00598.x

[49] Jiang, S., Fang, Q., Zhang, F., Wan, H., Zhang, R., Wang, C., et al. (2011) Functional Characterization of Insulin Receptor Gene Mutations Contributing to Rabson-Mendenhall Syndrome-Phenotypic Heterogeneity of Insulin Receptor Gene Mutations. Endocrine Journal, 58, 931-940. http://dx.doi.org/10.1507/endocrj.EJ11-0032

[50] Crown Human Genome Center, Weizmann Institute of Science. Insulin Receptor. http://www.genecards.org/cgi-bin/carddisp.pl?gene=INSR

[51] Sale, E.M., Atkinson, P.P., Arnott, C.H., Chad, J.E. and Sale, G.J. (1999) Role of ERK1/ERK2 and p70S6K Pathway in Insulin Signalling of Protein Synthesis. FEBS Letters, 446, 122-126. http://dx.doi.org/10.1016/S0014-5793(99)00193-3

[52] Finlay, D., Healy, V., Furlong, F., O’Connell, F.C., Keon, N.K. and Martin, F. (2000) MAP Kinase Pathway Signaling Is Essential for Extracellular Matrix Determined Mammary Epithelial Cell Survival. Cell Death \& Differentiation, 7, 302-313. http://dx.doi.org/10.1038/sj.cdd.4400652

[53] Ogunyemi, D., Xu, J., Mahesan, A., Rad, S., Kim, E., Yano, J., Alexander, C., Rotter, J.I. and Ida Chen, Y.-D. (2013) Differentially Expressed Genes in Adipocytokine Signaling Pathway of Adipose Tissue in Pregnancy. Journal of Diabetes Mellitus, 3, 86-95. http://dx.doi.org/10.4236/jdm.2013.32013 